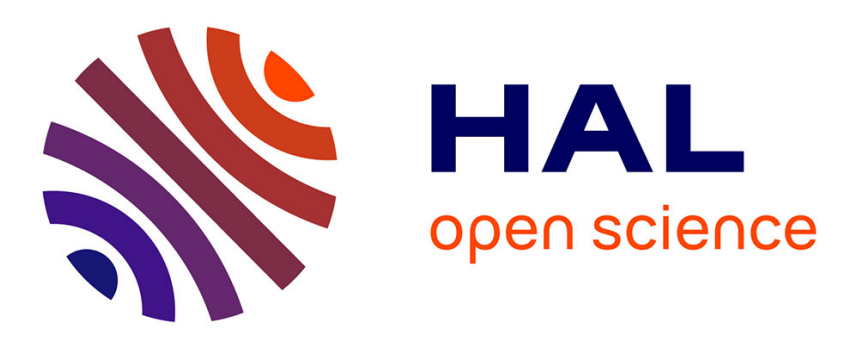

\title{
Silver and thallium historical trends in the Seine River basin
}

Sophie Ayrault, Cindy Rianti Priadi, O. Evrard, Irène Lefevre, Philippe Bonté

\section{To cite this version:}

Sophie Ayrault, Cindy Rianti Priadi, O. Evrard, Irène Lefevre, Philippe Bonté. Silver and thallium historical trends in the Seine River basin. Journal of Environmental Monitoring, 2010, 12 (11), pp.2177. 10.1039/C0EM00153H . cea-02615667

\section{HAL Id: cea-02615667 https://hal-cea.archives-ouvertes.fr/cea-02615667}

Submitted on 23 May 2020

HAL is a multi-disciplinary open access archive for the deposit and dissemination of scientific research documents, whether they are published or not. The documents may come from teaching and research institutions in France or abroad, or from public or private research centers.
L'archive ouverte pluridisciplinaire HAL, est destinée au dépôt et à la diffusion de documents scientifiques de niveau recherche, publiés ou non, émanant des établissements d'enseignement et de recherche français ou étrangers, des laboratoires publics ou privés. 


\section{Silver and thallium historical trends in the Seine River basin}

3 Sophie Ayrault ${ }^{1, *}$, Cindy Rianti Priadi ${ }^{1}$, Olivier Evrard ${ }^{1}$, Irène Lefèvre ${ }^{1}$, Philippe

4 Bonté ${ }^{1}$

5

6

${ }^{1}$ Laboratoire des Sciences du Climat et de l'Environnement (LSCE/IPSL), UMR 1572

7 (CEA/CNRS/UVSQ), Gif-sur-Yvette, France

8

9 Corresponding author:

10 Sophie Ayrault

11 Laboratoire LSCE

12 Domaine du CNRS

13 Avenue de la Terrasse, bat 12

1491198 Gif-sur-Yvette, France

$15 \quad$ Tel : $33(0) 169824354$

16 E-mail : sophie.ayrault@1sce.ipsl.fr

\section{Abstract}

Records on pollution by metals of minor economic importance (e.g. silver, thallium) but which prove to be toxic are rarely documented in river sediment. This study used two sediment cores collected downstream of the Seine River to describe the temporal evolution of $\mathrm{Ag}$ and $\mathrm{Tl}$ concentrations in an urban catchment. Radionuclide analysis (i.e. Cs-137 and Pb210) allowed dating sediment deposition within the cores (1933-2003). Ag concentration reached maximum values of $14.3-24.6 \mathrm{mg} \mathrm{kg}^{-1}$ in the $1960 \mathrm{~s}$ and $1970 \mathrm{~s}$, before gradually decreasing up to values which approximated $4 \mathrm{mg} \mathrm{kg}^{-1}$ in 2003. In contrast, Tl concentrations remained roughly constant throughout the core (median value of $0.86 \mathrm{mg} \mathrm{kg}^{-1}$ ). Suspended solids was collected at upstream locations in the catchment to derive the background concentrations in $\mathrm{Ag}$ and $\mathrm{Tl}$. Very high $\mathrm{Ag}$ concentrations were measured in the upstream Seine River sites $\left(0.33-0.59 \mathrm{mg} \mathrm{kg}^{-1}\right)$, compared to the values reported in the literature $\left(0.055 \mathrm{mg} \mathrm{kg}^{-1}\right)$. This suggests the presence of a widespread and ancient $\mathrm{Ag}$ pollution in the

32 Seine River basin, as demonstrated by the very high Ag enrichment ratios recorded in the 33 cores. Annual flux of particulate Ag in the Seine River was estimated at $1.7 \mathrm{t} \mathrm{yr}^{-1}$ in 2003 . In 
Silver and thallium historical trends in an urban catchment

34 contrast, $\mathrm{Tl}$ concentrations remained in the same order of magnitude as the natural 35 background signal $\left(0.3-0.5 \mathrm{mg} \mathrm{kg}^{-1}\right)$. This study suggests that the Seine River basin is free of $36 \mathrm{Tl}$ contamination. Future concerns should hence mostly rely on Ag contamination, in a 37 context of increasing Ag uses and possible releases to the environment. 38 
Silver and thallium historical trends in an urban catchment

\section{Introduction}

The presence of metals in the environment is known to be harmful and dangerous for fauna, biota and even for human health ${ }^{1,2}$. So far, research effort has focused on the behaviour of economically important trace metals $(\mathrm{Cr}, \mathrm{Hg}, \mathrm{Ni}, \mathrm{Pb}, \mathrm{Zn})$. Nevertheless, other metals such as silver (Ag) and thallium (Tl) are also particularly toxic. Silver and thallium were assigned to the highest toxicity class, together with cadmium and mercury. Still, the environmental impacts of $\mathrm{Ag}$ and $\mathrm{Tl}$ anthropogenic emissions are poorly documented, which is probably due to their low abundance in the environment.

Whereas silver and thallium are rather scarce in the crust $\left(0.08 \mathrm{mg} \mathrm{kg}^{-1}\right.$ for silver and $0.1-1.7 \mathrm{mg} \mathrm{kg}^{-1}$ for thallium ${ }^{3}$ ), they can concentrate in sediment and bio-accumulate in organisms (e.g. in benthic invertebrates) ${ }^{4}$. Silver has been used by people and extracted from argentiferous lead ores since ancient times. People first considered it as a precious metal and used it to make currency coins and jewellery. Its use has now greatly diversified and $\mathrm{Ag}$ is found in photographic films, electrical devices, batteries, brazing alloys and electroplating, coins and metals ${ }^{5}$. In 1995, photographic manufacturing represented $50 \%$ of the U.S. silver demand, whereas electrical contacts and conductors only accounted for $15 \%$ of the total demand. With the fast development of digital photography, silver applications in this domain sharply decreased (from $26 \%$ in 1999 to $12.5 \%$ in $2008{ }^{6}$ ), whereas silver use in electronic components greatly increased. Overall, the annual world demand in Ag increased significantly, from $13500 \mathrm{t} \mathrm{yr}^{-1}$ in $1995^{7}$ to $24500 \mathrm{t} \mathrm{yr}^{-1}$ in $2005^{8}$. These authors estimated the global emissions of silver to the environment at $13420 \mathrm{t} \mathrm{yr}^{-1}$, from which ca. $457 \mathrm{t} \mathrm{yr}^{-1}$ were dissipated to water between 1997-2000.

Contrary to $\mathrm{Ag}$, thallium was only discovered in 1861 and it mainly served as a rat killer in the past. However, $\mathrm{Tl}$ has not been as widely used as Ag. It is for instance used to make thermometers and photocells, and $60 \%$ of thallium is used by the US electronics 
Silver and thallium historical trends in an urban catchment

65

66

industry. Tl world production reached only $30 \mathrm{t} \mathrm{yr}^{-1}$ in $1984^{7}$. Because of the volatile nature of $\mathrm{Tl}$ compounds, $\mathrm{Tl}$ is readily emitted to the atmosphere by coal combustion, cement production, metal smelting and refining, as well as waste incineration ${ }^{9}$. Furthermore, half of the environmental emission is released to water, as reported in the US Environmental Protection Agency consumer factsheet devoted to thallium in drinking water and its impacts on public health (see http://www.epa.gov/ogwdw000/contaminants/dw_contamfs/thallium.html).

The historical evolution of $\mathrm{Ag}$ and $\mathrm{Tl}$ atmospheric concentrations was documented by several studies carried out in the northern hemisphere. Analyses were carried out on snow and ice samples collected at the Mont Blanc ${ }^{10}$; ombrotrophic peat bog samples from Switzerland ${ }^{11}$; sediment cores from boreal and remote, Swedish lakes ${ }^{12}$; and Artic snow and ice cores ${ }^{13}$. These studies indicate a regional and long-range contamination of ecosystems by atmospheric deposition for both $\mathrm{Ag}$ and $\mathrm{Tl}$.

In the case of the Swedish boreal and remote lakes, a contribution from the catchment geological background to the Ag concentration was not excluded ${ }^{12}$. The authors concluded to an Ag contamination of the recent sediment due to the atmospheric deposition that occurred after the Second World War. Furthermore, analyses of snow and ice collected at the French Alps indicate an increase in Ag atmospheric deposition after $1950^{10}$. This increase is related to the increase in $\mathrm{Ag}$ production extracted from argentiferous lead ores. In Artic snow and ice cores, a huge Ag peak was observed around 1960 and associated it with the economic boom that occurred after the Second World War ${ }^{13}$. A huge Ag peak dating from 1967 was also registered in ombrotrophic peat bog samples from Switzerland ${ }^{11}$. Even though $\mathrm{Ag}$ concentration has continuously increased since the beginning of last century, the average concentration found in samples of Arctic snow and ice in recent times are in the same order of 
Silver and thallium historical trends in an urban catchment

89

magnitude of the enrichments already observed during the Medieval, Roman and Greek/Phoenician periods.

Data on $\mathrm{Tl}$ historical trends are even scarcer than for $\mathrm{Ag}$, and the conclusions are somewhat different from one study to another. Tl concentrations have been increasing since the mid-1800s, but the most prominent increase took place after the Second World War, as it is recorded in lake sediment cores ${ }^{12}$. This increase is consistent with the 1967 peak observed in peat bogs ${ }^{11}$. The highest $\mathrm{Tl}$ concentrations were observed for the years 1870 and 1920 in Artic ice core ${ }^{13}$ but a similar peak as the one observed for Ag concentrations in the 1960s was not identified for Tl. Ag and Tl experienced hence different historical evolutions. A decrease in both $\mathrm{Ag}$ and $\mathrm{Tl}$ concentrations was nevertheless observed during the last decade.

Overall, the former studies observed the occurrence of a significant $\mathrm{Ag}$ and $\mathrm{Tl}$ contamination in the environment after the Second World War, and they related it to the industrialisation of Europe. Ag contamination was observed in ancient archives (8000-300 BP). A decrease in $\mathrm{Ag}$ and $\mathrm{Tl}$ environmental concentrations was only detected during the last decade in archives exhibiting the highest temporal resolution (i.e. ice cores). These studies suggest that $\mathrm{Ag}$ and $\mathrm{Tl}$ release to the environment are controlled by independent sources and/or processes.

The availability of techniques to detect $\mathrm{Tl}$ at very low concentrations is recent ${ }^{14}$. Data on $\mathrm{Tl}$ concentrations in lakes are rather alarming (e.g. at the Great Lakes ${ }^{15}$ ). However, similar data are scarce for rivers. Still, obtaining information on the historical evolution of $\mathrm{Tl}$ and $\mathrm{Ag}$ concentrations in urban catchments is crucial, given river water is used as a supply source for human consumption in densely urbanised areas. Furthermore, the secondary mobilisation of heavy metals from overbank sediment has been demonstrated ${ }^{16}$.

Ag is found to be mostly bound to sulphides and organic matter. It is strongly sorbed to suspended particles. In river systems, it is rapidly incorporated into sediment and most of 
Silver and thallium historical trends in an urban catchment

114 the dissolved silver $(<0.45 \mu \mathrm{m}$ filtration $)$ is associated with colloids ${ }^{17}$. This high affinity for

115 suspended matter would explain why $90 \%$ of Ag are found in the solid phase once they reach

116 the estuary because of dissolved Ag scavenging by organic matter ${ }^{18}$. In this context, analysis

117 of sediment cores sampled in river floodplains can offer a solution to determine the

118 concentrations in this metal. With respect to $\mathrm{Tl}$, the partitioning between the dissolved and

119 solid phases remains the subject of lively debate ${ }^{19}$. Nevertheless, it seems reasonable to

120 hypothesise that the occurrence of a severe pollution in $\mathrm{Tl}$ would be recorded in sediment

121 despite the dominance of the dissolved fraction. We propose hence to analyse two sediment

122 cores collected in the Seine River basin, which is one of the most polluted areas in the world

123 in terms of metal contamination ${ }^{20,21}$.

124 This study aims to derive the historical trends of Ag and Tl contamination in the Seine

125 River basin. $\mathrm{Ag}$ and $\mathrm{Tl}$ concentrations in sediment will be compared to the natural

126 geochemical background concentrations. Sediment samples collected at upstream sites

127 considered as only slightly impacted by human activities will be analysed to define the local

128 geochemical background level. Scandium (Sc) will be used as a reference element, because of

129 its conservative behaviour, to evaluate the anthropogenic impact of $\mathrm{Ag}$ and $\mathrm{Tl}$ on river

130 contamination ${ }^{11,13}$. Finally, the main sources of $\mathrm{Ag}$ and $\mathrm{Tl}$ delivery to the river will also be

131 outlined.

\section{Experimental}

\section{Study area and selection of the coring sites}

135 Two cores were collected in the Seine River floodplain, about $100 \mathrm{~km}$ downstream of Paris

136 and its main waste waster treatment plant (Seine - Aval waste water treatment plant at

137 Achères). The sampling sites drain $96 \%$ of the Seine River basin and are located within the

138 last major meander of the Seine River before it reaches its estuary. 
Silver and thallium historical trends in an urban catchment

The first site (i.e. Bouafles) is located just upstream of a dam, in 'Les Andelys' (Fig.

140 1), in an oxbow lake located on the right bank of the Seine River. It corresponds to a recent

141 accretion area as indicated by the recent burial of trees. This undisturbed sampling area has

142 remained under grassland for 30 years, and gradual sediment deposition has occurred. Local

143 inhabitants confirmed indeed that the site has been flooded at least once each year until 2004.

144 The analysis of eleven cores collected in the area between 2003-2008 demonstrated that they

145 correspond to the sedimentation that occurred during the last 60 years (see ${ }^{21}$ for details).

146 The second site (i.e. Muids) is located in the same meander and on the same bank of

147 the Seine River, but $12 \mathrm{~km}$ further on downstream. This site is composed by four islands

148 which experienced regular flooding during winter.

150 Core sampling

151 Three cores were sampled in each site on April 9, 2003 using an Eijkelkamp device

152 equipped with a percussion drill bit (with 10-cm diameter and 1-m length). The soil corer 153 could be opened laterally, which allowed an immediate transfer of the core into a PVC tube to 154 prevent its contamination by metals.

156 Core dating

157 Dating of the sediment cores relied on the measurement of two radionuclides (i.e. Cs158137 and $\mathrm{Pb}-210$ ) that strongly sorb to fine sediment ${ }^{22,23}$. Cs-137 was used as an event-tracer, 159 whereas $\mathrm{Pb}-210$ provided the sediment age.

160 Both radionuclides are gamma emitters and they can be detected in small quantities of 161 soil (ca. 50-100 g, typically) without any previous chemical treatment. Sediment was dried at $162115^{\circ} \mathrm{C}$, sieved $(<2 \mathrm{~mm})$, ground to a fine powder and placed in air-tight counting boxes.

163 Counting was conducted during ca. $10^{5} \mathrm{~s}$ using Germanium gamma-ray detectors 
Silver and thallium historical trends in an urban catchment

164 (Germanium hyperpure - GeHP, N-type, coaxial model) available at the Laboratoire des

165 Sciences du Climat et de l'Environnement (Gif-sur-Yvette, France). Efficiencies and 166 background of the detectors were periodically controlled with internal soil and sediment 167 standards, pure $\mathrm{KCl}$ samples, and IAEA standards (i.e. Soil-6, -135 and -375). Activity decay 168 was corrected taking account of the sediment collection period.

169 Cs-137 is an artificial radionuclide $\left(\mathrm{t}_{1 / 2}=30\right.$ years) produced by the thermonuclear 170 bomb testing conducted between the 1950s and the 1980s (with a maximum input in 1964) 171 and the Chernobyl accident in 1986. Measurement of Cs-137 activity in sediment allowed 172 determining the location of three events: the fallout due to the first significant input in the 173 atmosphere in 1954, the maximum input in 1964 and the fallout due to the Chernobyl 174 catastrophe in 1986. Cs-137 is now stored in soils, and this Cs-137 stock decreases by 175 radioactive decay and by fine sediment transfer to the rivers. Cs-137 is easily identified in 176 gamma spectrometry by a peak at $661 \mathrm{keV}$. Uncertainty on measurements was ca. $0.5 \%$, and 177 the detection limits reached $0.3 \mathrm{~Bq} \mathrm{~kg}^{-1}$.

$178 \mathrm{~Pb}-210$ is a natural radionuclide $\left(\mathrm{t}_{1 / 2}=22.3\right.$ years $)$ which is a decay product of $\mathrm{U}-238$ $179\left(\mathrm{t}_{1 / 2}=4.510^{9}\right.$ years $) . \mathrm{U}-238$ decays through a series of short-lived nuclides (e.g. Ra-226, Rn180 222). Rn-222 is a gas that partly remains in situ, forming "supported" $\mathrm{Pb}-210$, and that partly 181 escapes to the atmosphere, forming "excess" $\mathrm{Pb}-210$, which reaches the soil surface by wet 182 and dry fallout. It then strongly sorbs to soil particles. The activity in "excess" $\mathrm{Pb}-210$ was 183 calculated by subtracting the supported activity (determined using a U-238 daughter, i.e. Bi184 214) from the total activity of $\mathrm{Pb}-210^{24}$. Uncertainty on measurements was thus higher than 185 for Cs-137 (ca. 10\%).

\section{Suspended matter sampling}


Silver and thallium historical trends in an urban catchment

In order to determine the background values for $\mathrm{Ag}$ and $\mathrm{Tl}$ in the river, suspended matter (SM) was collected in the Seine and Marne rivers at upstream locations (i.e. at Marnay-sur-Seine and Méry-sur-Marne; Fig. 1a). At Méry-sur-Marne, water was collected on two field campaigns (April 2006 and January 2007) by grab sampling with PVC buckets from the river bank. Twenty-liter samples were stored in PVC jerrycans thoroughly rinsed with alkaline detergent TFD- ${ }^{\circledR}$. SM was obtained by gravitational settling of the samples during several days. Uplying water was eliminated and approximately two litres of water were centrifuged at $3000 \mathrm{rpm}$. Finally, recovered SM was freeze-dried. At Marnay-sur-Seine, SM was collected in sediment traps from December 2008 to February 2009. These traps consisted in 1.5-liter PET water bottles ${ }^{25}$. They were emptied once a month, providing SM data at a monthly time step. Samples were collected in polyethylene bottles thoroughly rinsed with $1 \mathrm{M}$ $\mathrm{HNO}_{3}$ for several days. Samples were then centrifuged at $14000 \mathrm{rpm}$ and vacuum-dried.

\section{Elemental analysis.}

$\mathrm{Sc}$ and $\mathrm{Ag}$ concentrations were measured using INAA (Instrumental Neutron Activation Analysis) analyses conducted on bulk sediment powder. Fifty-mg samples were irradiated during 30 minutes by a flux of $2.310^{13}$ neutrons $\mathrm{cm}^{-2} \mathrm{~s}^{-1}$ in the experimental reactor Orphée (Commissariat à l'Energie Atomique, Saclay, France), using the irradiation facilities of the Laboratoire Pierre Süe. Four successive gamma spectrometry measurements were then conducted using Germanium gamma-ray detectors (Germanium hyperpure - GeHP, N-type, coaxial model). Ag and Sc concentrations were determined using the 10-h counting after a 30 days-decay.

$\mathrm{Ag}$ and $\mathrm{Tl}$ concentrations were measured using ICP-MS (Inductively Coupled Plasma - Mass Spectrometry) on totally digested samples. One hundred mg-samples were totally dissolved by successive additions of $\mathrm{HNO}_{3}$ and $\mathrm{HCl}$ mixture, $\mathrm{HF}$, and $\mathrm{HClO}_{4}$ in Teflon 
Silver and thallium historical trends in an urban catchment

213 vessels using a heating block (Digiprep, SCP Science). Ultra pure reagents were used 214 (Normatom grade, VWR, France for $\mathrm{HNO}_{3}$, and $\mathrm{HCl}$, “for trace metal analyses", Baker, 215 SODIPRO, France, for $\mathrm{HF}$, and $\mathrm{HClO}_{4}$ ). The solutions were evaporated to dryness, retaken 3 216 times in $2 \mathrm{ml}$ of $\mathrm{HNO}_{3}$ and then diluted with $50 \mathrm{~mL}$ of MilliQ water. The concentrations were 217 determined by Inductively Coupled Plasma - Quadrupolar Mass Spectrometry ICP-QMS (X 218 Series, ThermoElectron, France). To correct for instrumental drifts and plasma fluctuations, 219 all solutions were spiked with rhodium $(\mathrm{Rh})$ and rhenium $(\mathrm{Re})$ standard solutions (SPEX, SCP 220 Science, France) to a final concentration of $10 \mu \mathrm{g} \mathrm{L}^{-1}$ for $\mathrm{Rh}$ and $1 \mu \mathrm{g} \mathrm{L}^{-1}$ for Re. The 221 solutions were weighted at each step of the dilution and spiking operations.

We only provide the Ag ICP-MS results for the suspended sediment collected at Méry-sur-Marne and Marnay-sur-Seine, because this technique offers lower detection limits than INAA (Table 1). The combined errors of the concentration measurements (Ag INAA, Sc INAA, Ag and Tl ICP-MS) were estimated to be in the order of $10 \%, 8 \%$ and $5 \%$, respectively. The accuracy of the analytical data was checked by analysing the GXR-1 reference material (jasperoid, USGS) by both methods. The measured concentrations in GXR-1 agreed with the recommended $\mathrm{Ag}$ and Sc concentration values, and with the $\mathrm{Tl}$ provisional concentration value (Table 1). The enrichment factors (EF) in both $\mathrm{Ag}$ and $\mathrm{Tl}$ were calculated based on the methodology developed by Wedepolhl ${ }^{26}$ (Eq. 1).

$$
\mathrm{EF}=([\mathrm{M}] /[\mathrm{Sc}])_{\text {Sample }} /([\mathrm{M}] /[\mathrm{Sc}])_{\text {Natural background }}(1)
$$

233 where $M$ represents $\mathrm{Ag}$ or $\mathrm{Tl}$ and using the natural background values of $\mathrm{Ag} / \mathrm{Sc}(0.08)$ and $234 \mathrm{Tl} / \mathrm{Sc}(0.10)^{26}$.

\section{Results and discussion}


Silver and thallium historical trends in an urban catchment

The cores (i.e. B2 for the Bouafles site and M1 for the Muids site) used in this study were selected because of their reliable record of sedimentation.

The depth profile of Cs-137 in the B2-core is shown in Fig. 2a. The events corresponding to the 1986 and 1964 fallout were clearly recorded. In depth, no Cs-137 was detected anymore, indicating that the core includes sediment deposited before 1954 .

243 Sedimentation rate derived from the excess $\mathrm{Pb}-210$ profile appeared to be constant throughout 244 the core, and the sedimentation rate derived from the chronology of the core reached $1.8 \mathrm{~cm}$ $245 \mathrm{yr}^{-1}$.

With respect to the M1-core, sedimentation rates appeared to have varied throughout 247 time (Fig. 2b). Chernobyl fallout is located at 14-cm depth, whereas the maximum Cs-fallout 248 that occurred in 1964 is located at 43-cm depth (Fig. 2c). Calculated sedimentation rates 249 sharply decreased throughout time, from $2.5 \mathrm{~cm} \mathrm{yr}^{-1}$ before 1964, to $1.3 \mathrm{~cm} \mathrm{yr}^{-1}$ between 1964 250 and 1986, and only $0.8 \mathrm{~cm} \mathrm{yr}^{-1}$ between 1986 and 2003. This gradual decrease in 251 sedimentation was due to the progressive burial of the river bed by suspended matter 252 deposition at this location.

\section{Ag and Tl concentrations at upstream sites of the Seine River basin}

Mean concentrations in Ag measured in the sediment collected at Marnay-sur-Seine $\left(0.33 \pm 0.15 \mathrm{mg} \mathrm{kg}^{-1}\right)$ and at Méry-sur-Marne $\left(0.59 \pm 0.01 \mathrm{mg} \mathrm{kg}^{-1}\right)$ are about tenfold higher than the Ag upper continental crust background values $\left(0.055 \mathrm{mg} \mathrm{kg}^{-1}\right)$ (Table 2) ${ }^{3,26}$.

Three explanations can be put forward to explain this difference. First, the high Ag concentrations measured in the Seine River could indicate that the geochemical background values are exceptionally high in this river. However, we rule out this hypothesis, because of

261 the dominant sedimentary origin of the rocks in the Seine River basin. Second, they could 262 indicate that the Seine River basin underwent a general and very ancient pollution. This 
Silver and thallium historical trends in an urban catchment

263

264

265

266

267

268

second hypothesis seems more likely. Such a large contamination by atmospheric deposition has also been observed in remote environmental archives ${ }^{13}$. Third, this contamination could be explained by Ag released by lead $(\mathrm{Pb})$ industries present in the Upper Seine and the Marne catchments. $\mathrm{Pb}$ and $\mathrm{Ag}$ are indeed strongly associated in $\mathrm{Pb}$-ores. Even though the activity of lead industrial facilities strongly decreased after 1970 in the Seine River basin ${ }^{27}$, there are still a dozen plants in activity in the Upper Seine and the Marne catchments (Fig. 1b) ${ }^{28}$.

Overall, data are still too scarce to draw conclusions about the high Ag geochemical background signal in the Seine River basin. Sediment deposited before the protoindustrialisation in the region needs to be collected and analysed to derive this signal.

In contrast, thallium concentrations measured at Marnay-sur-Seine $\left(0.30 \mathrm{mg} \mathrm{kg}^{1}\right)$ and Méry-sur-Marne $\left(0.45 \mathrm{mg} \mathrm{kg}^{-1}\right)$ (Table 2) are in good agreement with the median $\mathrm{Tl}$ concentration in European floodplain sediment ${ }^{29}$. They were even lower than the $\mathrm{Tl}$ geochemical background concentrations reported in the upper continental crust $\left(0.75 \mathrm{mg} \mathrm{kg}{ }^{-}\right.$

${ }^{1}$ ). The low $\mathrm{Tl}$ concentrations that we observed could be explained by the dilution of the geological $\mathrm{Tl}$ input by autochthonous calcite and/or organic matter. Scandium (Sc) concentrations were measured in all the samples. Normalising Tl concentrations to Sc allows taking account of this dilution effect. The Tl/Sc ratio for the reference geochemical background varies between 0.068 and 0.107 . According to our data, the $\mathrm{Tl} / \mathrm{Sc}$ ratio reached $0.046 \pm 0.005$ at Marnay-sur-Seine and $0.062 \pm 0.001$ at Méry-sur-Marne. These low Tl concentrations measured at upstream sites of the Seine River basin cannot be explained by a dilution effect. It is more reasonable to attribute these low concentrations to the sedimentary origin of the rocks in the Seine River basin. Moreover, the $\mathrm{Tl}$ concentration observed at Marnay-sur-Seine lower than the Tl concentration at Méry-sur-Marne may be partly explained by a possible metal release from the suspended sediments trapped during one month periods at Marnay-sur-Seine. 
Silver and thallium historical trends in an urban catchment

\section{Depth profiles of Ag and Tl concentrations}

Sc, Ag and Tl concentrations measured along the sediment profiles of the B2 and M1

cores as well as the estimated chronology of deposition are shown in Tables 3 and 4.

The Ag concentration showed strong variations along the profile of the B2 core (from

The lowest concentration $\left(3.8 \mathrm{mg} \mathrm{kg}^{-1}\right)$ was measured in the uppermost superficial layer which corresponds to the sediment deposited in 2003. Moreover, the peaks in $\mathrm{Ag}$ concentrations (observed in 1960 and, to a lesser extent, in 1994) correspond to similar peaks in $\mathrm{Zn}, \mathrm{Sb}, \mathrm{Hg}$ and $\mathrm{Pb}$ concentrations ${ }^{21}$. The 1960 peak probably reflects the industrial boom after the Second World War.

The depth profile of $\mathrm{Ag}$ concentration in the M1 core is similar to the one obtained in the other core, even though it is systematically characterised by slightly lower concentrations

(Table 4). Similar observations can be made for Sc concentrations. This indicates the presence of a less abundant clay fraction in M1 compared to B2.

To document the influence of anthropogenic activities, temporal variations of the $\mathrm{Ag}$ and $\mathrm{Tl}$ enrichment factors $(\mathrm{EF})$ ratios were calculated, taking account of the upper continental crust (UCC) concentrations as a reference (Table 5). The following EF values should be interpreted with some caution, keeping in mind the shortcomings of the EF approach, EF being calculated relative to the crust composition or to local background values ${ }^{30} \mathrm{Ag} \mathrm{EF}$ 308 recorded in both B2 and M1 cores were extremely high. EF in Ag ranged between 51 and 300 309 in B2 and between 73 and 263 in M1, when using UCC concentrations as reference values. 310 After normalising Ag concentrations to Sc, the Ag EF depth profiles were much more similar 311 in both cores (Fig. 3). Ag EF obtained taking the concentrations measured at Marnay-sur312 Seine as a reference ranged from 8 to 47 in the B2 core and from 12 to 39 in the M1 core. 
Silver and thallium historical trends in an urban catchment

313 When using the concentrations at Méry-sur-Marne, Ag EF fluctuated similarly between 12 314 and 44 in the B2 core, and 12 and 26 in the M1 core. These results demonstrate a significant 315 enrichment of sediment in Ag and $\mathrm{Tl}$ during its transfer from the upper catchment sites to the 316 downstream sites. This enrichment is clearly associated with contemporary anthropogenic 317 impacts, whereas the enrichment observed at the upstream sites was probably induced by 318 more ancient human activities.

Given it is widely known that Pb-ores constitute an important $\mathrm{Ag}$ source ${ }^{31}$, it is particularly relevant to compare the Ag concentrations with the ones obtained for $\mathrm{Pb}^{21}$. Both profiles were found to be synchronous (results not shown). Examination of the $\mathrm{Pb} / \mathrm{Ag}$ ratio can provide valuable insights about the dominant emission processes ${ }^{11}$. The $\mathrm{Pb} / \mathrm{Ag}$ ratio decreased from ca. 50 in sediment deposited in 1930, up to 20 in the 2003 sediment. The higher enrichment in $\mathrm{Pb}$ than in Ag observed in the Swiss peat bog ${ }^{11}$ level corresponding to 1967 is not observed in the Seine River sediment. In addition, the Pb/Ag ratios observed in the Seine sediment cores are significantly lower than those observed in peat bog ${ }^{11}$ and even lower than the $\mathrm{Pb} / \mathrm{Ag}$ ratio reported in $\mathrm{UCC}$ (i.e. $400^{3}$ ). Overall, we can confidently state that the Seine River sediment is enriched in Ag compared to $\mathrm{Pb}$.

$\mathrm{Tl}$ concentrations in the $\mathrm{B} 2$ core ranged between 0.66 and $1.01 \mathrm{mg} \mathrm{kg}^{-1}$, with a median concentration of $0.86 \pm 0.12 \mathrm{mg} \mathrm{kg}^{-1}$ all throughout the depth profile. No significant peak can be detected in the profile (Table 3). The lowest Tl concentration in sediment was measured in 332 the sediment deposited in 1979. Furthermore, Tl EF mean values were close to 1 (0.9 in average) (Table 5) when taking the UCC concentrations as a reference, indicating an absence of enrichment. Tl EF calculated using concentrations measured at Marnay-sur-Seine and Méry-sur-Marne reached 2.1 and 1.5, respectively. The low but constant enrichment in $\mathrm{Tl}$ measured in the downstream sediment suggests the potential existence of a natural Tl source 337 in the Seine River basin. We suspect that the Yonne river sediment could be responsible for 
Silver and thallium historical trends in an urban catchment

this Seine sediment enrichment in Tl. The Yonne river flows indeed into the Seine River at a junction located downstream of Marnay-sur-Seine (Fig. 1a), after having flown across granites exposed in the Morvan region. Granites are known to be enriched in $\mathrm{Tl}^{7}$.

\section{Thallium pollution records in the sediment cores}

Atmospheric archives are characterised by an important $\mathrm{Tl}$ pollution, which is even more important than Ag pollution ${ }^{11,12,13}$. Our results clearly point out that the increase in $\mathrm{Tl}$ atmospheric source(s) measured in atmospheric archives did not impact the composition of the Seine River sediment. The geochemical behaviour of $\mathrm{Tl}$ is similar to the one of potassium and other alkali metal cations ${ }^{31,32}$. The lability of Tl may bring into question the relevance of a sediment core to record a $\mathrm{Tl}$ pollution signal. However, this issue remains the object of a lively debate in the literature. On the one hand, mobilisation of $\mathrm{Tl}$ from the solid phase to pore waters was observed in lacustrine sediment cores ${ }^{12,33}$. Laforte et al. $(2005)^{33}$ concluded that the significant post-depositional $\mathrm{Tl}$ mobility must be taken into account to interpret $\mathrm{Tl}$ profiles in sediment. On the other hand, it was also shown that $\mathrm{Tl}$ sorbed strongly on layered illitic and vermiculite clays ${ }^{19}$. Moreover, no $\mathrm{Tl}$ desorption was observed from clay-rich soils when adding $\mathrm{NH}_{4}{ }^{+}$and $\mathrm{K}^{+}$competitive cations. $\mathrm{Tl}$ is even considered to be enough stable to allow its chronological evaluation ${ }^{34}$. The strong sorption of $\mathrm{Tl}$ from atmospheric origin on silty and silty-clay soils of France was demonstrated ${ }^{32}$. It was also showed that $\mathrm{Tl}$ present in the French soils had a pedological origin.

Consequently, it seems reasonable to conclude that, if a significant $\mathrm{Tl}$ contamination had affected the Seine River basin, it would have been recorded, at least partly, in the river sediment. Given the absence of any pollution signal in the B2 and M1 sediment cores, we can conclude to the absence of any significant $\mathrm{Tl}$ contamination in the Seine River sediment between the 1940s and today. 
Silver and thallium historical trends in an urban catchment

The need to further investigate the partitioning of $\mathrm{Tl}$ between the solid and dissolved phases in soils was outlined ${ }^{19}$. Future investigations could also usefully determine $\mathrm{Tl}$ partitioning between the sediment and the dissolved phase in rivers. Solid/dissolved partitioning of $\mathrm{Tl}$ is of primary importance because of the high toxicity of soluble $\mathrm{Tl}$ compounds. Moreover, obtaining this value would allow calculating the dissolved fluxes based on the particulate fluxes which are much easier to measure.

\section{Potential sources of Ag to the river}

Ag may be released by different sources to the environment. Thouvenin et al. (2005) ${ }^{18}$ estimated the silver contribution of the Seine River to its estuary in 2003. Sediments were monthly sampled in Poses, which is the last dam before the estuary. In 2003, the Ag flux in Poses was estimated at $1.5{\mathrm{t} \mathrm{yr}^{-1}}^{18}$. Based on the measurements obtained from the B2 sediment core sampled in 2003 at Bouafles, which is located $30 \mathrm{~km}$ upstream of Poses, we can propose a rough and comparative estimation of the Ag annual flux. The particulate output of the Seine was estimated at $450,000 \mathrm{t} \mathrm{yr}^{-1}$ in $2003^{18}$. Ag concentration in the uppermost layers of the $\mathrm{B} 2$ core reached $3.8 \mathrm{mg} \mathrm{kg}^{-1}$, we can then estimate the particulate $\mathrm{Ag}$ output

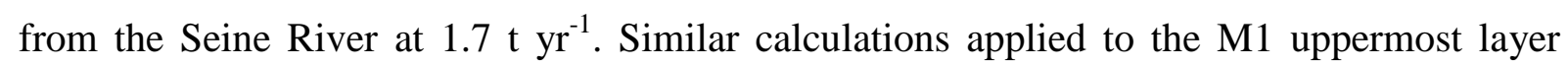
concentration result in an $\mathrm{Ag}$ particulate flux of $2.0 \mathrm{t} \mathrm{yr}^{-1}$. Both estimations remain in good agreement with the ones obtained previously ${ }^{18}$, given that the concentrations in the uppermost layer of the core are only representative of the solids concentration reached during periods of high water level. Moreover, suspended sediment ${ }^{18}$ and deposited sediment (this work) differ in terms of particle size and organic matter content. Still, these characteristics influence the metal concentration in sediment. Overall, our results suggest that the Ag export

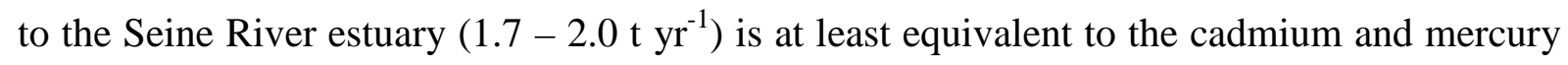
fluxes at the river mouth (1.75 and $1.25 \mathrm{t} \mathrm{yr}^{-1}$, respectively $\left.{ }^{27}\right)$. Given the high toxicity of $\mathrm{Ag}$, 
Silver and thallium historical trends in an urban catchment

Ag concentrations in the solid and the dissolved phases should be monitored to evaluate precisely the Ag particulate and dissolved fluxes from the river and to allow conducting further risk assessment studies.

It is necessary to determine the potential sources delivering Ag to the river in order to propose potential remediation regulations. Metal mining and smelting activities are known to constitute the major $\mathrm{Ag}$ contaminating sources to atmospheric and aquatic environments. However, there is no sulphide ore exploitation in the Seine River basin. In contrast, municipal waste incinerators could be an important source of Ag contamination in the Seine River. They incinerate domestic waste as well as electronic devices that were not sorted out for recycling. In the Seine River basin, more than $70 \%$ of the solid wastes are incinerated. $36 \%$ of discarded (not recycled) $\mathrm{Ag}$ in Europe are found in municipal solid wastes ${ }^{5}$. During the incineration process, silver ends up as bottom and fly ashes, and emissions to the atmosphere remain therefore limited ${ }^{17}$. Solid wastes issued from municipal waste incinerators contain the bulk of anthropogenic $\mathrm{Ag}^{5}$. Sewage sludge constitutes the second $\mathrm{Ag}$ source. Landfilling of solid wastes issued from thermal treatment incinerators and sewage sludge might constitute a delayed risk of Ag contamination if landfill contaminants were released to the environment by soil erosion.

Forty-five percents of the silver used in the film and photo production were not recycled and potentially exposed to the environment in $1997^{5}$. The film photography first developed at the end of the $19^{\text {th }}$ century and became a mass-consumption product throughout the $20^{\text {th }}$ century. This use may have induced a large part of the ancient sediment contamination, not only because of the lack of restrictive waste management regulations, but also because of the spreading of numerous photo laboratories. The exponentially decreasing demand for this use could explain the decrease in Ag concentration measured in the contemporary sediment. 
Silver and thallium historical trends in an urban catchment

Ag content in domestic waste is likely to increase again in future. A recent study carried out in the Rhine river catchment showed that the production of goods using $\mathrm{Ag}$ nanoparticles will increase in future. This will amplify the Ag release to freshwater environments ${ }^{17}$. These products consist in plastics (medical catheters, sanitation tubes, computer keyboards, door handles, car steering wheels and mobile phones) and textiles benefiting from the biocide effect of $\mathrm{Ag}$ nanoparticles. The biocidal mechanism of silvercontaining products results indeed from a long term release of silver ions $\left(\mathrm{Ag}^{+}\right)$by oxidation of metallic silver $\left(\mathrm{Ag}^{0}\right)$ in contact with aqueous media. Up to $15 \%$ of the total silver emitted to water in Europe may be released from biocidal plastics and textiles in $2010^{17}$.

\section{Conclusions}

Very few records were available to document the contamination by metals of minor economic importance such as $\mathrm{Ag}$ and $\mathrm{Tl}$ in river catchments strongly modified by human activities. These metals prove nevertheless to be very toxic. This study demonstrated that the Seine River sediment was not contaminated by $\mathrm{Tl}$ during the last 60 years. However, the question of its partition between the solid and the dissolved phases remains a subject of lively debate. In contrast, the Seine River sediment was severely contaminated by Ag. Concentration in this metal started decreasing in the 1960 s, but it is still present in the environment. Nowadays, the main source of $\mathrm{Ag}$ to the river sediment appears to originate from the waste incinerators. However, the sources of Ag may have changed throughout the last decades. Moreover, the increasing Ag demand and the growth of its uses demonstrate the necessity to understand the biogeochemical cycle of $\mathrm{Ag}$, which can partly be investigated through the analysis of environmental archives.

\section{Aknowledgements}


Silver and thallium historical trends in an urban catchment

438 We thank G. Varrault, B. Pernet-Coudrier and A. Bourgeault for their help for the collection

439 of suspended sediment. M.-F. Le Cloarec and J.-M. Mouchel are thanked for their active 440 participation to the sediment core collection and analysis. This work has been made possible

441 thanks to funding from the Piren-Seine programme, the French National Research Agency

442 (ANR) Biomet project and the EC2CO Medisis project. This is the LSCE contribution 443 number 4097.

444

445 
Silver and thallium historical trends in an urban catchment

446

447

448

449

450

451

452

453

454

455

456

457

458

459

460

461

462

463

464

465

466

467

468

469

470

471

472

473

474

475

476

477

478

\section{References}

1 J. O. Nriagu, Science, 1996, 272, 223-224.

2 R. P. Schwarzenbach, B. I. Escher, K. Fenner, T. B. Hofstetter, A. Johnson, U. von Gunten and B. Wehrli, Science, 2006, 313, 1072-1077.

3 S. R. Taylor and S. M. McLennan, The Continental Crust: Its Composition and Evolution, Blackwell Scientific, Oxford, 1985, 328 pp.

4 H. T. Ratte, Environ. Toxicol. Chem., 1999, 18, 89-108.

5 T. Lanzano, M. Bertram, M. De Palo, C. Wagner, K. Zyla and T. E. Graedel, Resources, Conservation and Recycling, 2006, 46, 27-43.

6 World Silver Survey, The Silver Institute and Gold Fields Mineral Services, Ltd., Washington, DC, 2009.

7 C. Reimann and P. De Caritat, Chemical Elements in the Environment. Factsheets for the Geochemist and Environmental Scientist, Berlin, Heidelberg, New York, London, Paris, Tokyo, Hong Kong: Springer-Verlag, 1999, 398 pp.

8 M. J. Eckelman and T. E. Graedel, Environ. Sci. Technol., 2007, 41, 6283-6289

9 J. O. Nriagu and J. M. Pacyna Environ. Rev., 1988, 9, 269-298.

10 K. Van de Velde, C. Barbante, G. Cozzi, I. Moret, T. Bellomi, C. Ferrari and C. Boutron, Atmos. Environ., 2000, 34, 3117-3127.

11 W. Shotyk and M. Krachler, J. Environ. Monit., 2004, 6, 427-433.

12 E. Grahn, S. Karlsson, U. Karlsson and A. Düker, J. Environ. Monit., 2006, 8, 732-744.

13 M. Krachler, J. Zheng, D. Fisher and W. Shotyk, Sci. Total Environ., 2008, 399, 78 - 89.

14 A. R. Flegal and C. C. Patterson, Marine Chemistry, 1985, 15, 327-331.

15 T. S. Lin, J. Nriagu and X. Q. Wang, Bull. Environ. Contam. Toxicol., 2001, 67, 921-925.

16 V. Cappuyns and V.Swennen, J. Environ. Monitor., 2004, 6, 434-440.

17 S. A. Blaser, M. Scheringer, M. MacLeod and K. Hungerbühler, Sci. Total Environ., 2008, 390, 396-409.

18 B. Thouvenin, B. Boutier, J.-F. Chiffoleau, J.-L. Gonzalez., D. Cossa, D. Auger, B. Averty, E. Rozuel-Chartier, D. Ménard, A. Santini and M. Olivier, Contribution à l'étude de la dynamique et de la spéciation des contaminants, Rapport d'activité 2004. Programme Seine Aval 3 (see also http://seine-aval.crihan.fr/web), 2005, 46 pp.

19 A R.Jacobson, M. B.McBride, P. Baveye and T. S. Steenhuis, Sci. Total Environ., 2005, $\mathbf{3 4 5}, 191-205$. 
Silver and thallium historical trends in an urban catchment

20 M. Meybeck, L. Lestel, P. Bonté, R. Moilleron, J.-L. Colin, O. Rousselot, D. Hervé, C. de Pontevès, C. Grosbois and D. R. Thévenot, Sci. Total Environ., 2007, 375 (1-3), 204-231.

21 M.-F. Le Cloarec, P. Bonté, L. Lestel, I. Lefèvre and S. Ayrault, Physics \& Chemistry of the Earth. in press

22 K. Wang and R. J. Cornett, Journal of Paleolimnology, 1993, 9, 179-188.

23 C. Gil-García, A. Rigol and M. Vidal, J. Environ. Radioact., 2009, 100, 690-696.

24 P. Bonté, J.-M. Mouchel, A. Thomas, M.-F. Le Cloarec, J-P. Dumoulin, S. Sogon and L. Tessier, Acta Geol. Hisp., 2000, 35, 339-355.

25 L. Tessier, Transport et caractérisation des matières en suspension dans le bassin de la Seine : identification de signatures naturelles et anthropiques, $\mathrm{Ph}$. D. thesis, Ecole Nationale des Ponts et Chaussée, France, 2003, 344 pp.

26 K. H. Wedepohl, Geochim. Cosmochim. Acta, 1985, 59, 1217-1232.

27 D. R. Thévenot, R. Moilleron, L. Lestel, M.-C. Gromaire, V. Rocher, P. Cambier, P. Bonté, J.-L. Colin, C. de Pontevès and M. Meybeck, Sci. Total Environ., 2007, 375 (1-3), 180-203.

28 IREP, Registre Français des Émissions Polluantes [French Register on Contaminant Emissions]. French Ministry of Ecology, Energy, Sustainable Development and Marine Affairs, Paris. (see also http://www.pollutionsindustrielles.ecologie.gouv.fr /IREP/index.php), 2009

29 R. Salminen, Geochemical Atlas of Europe. Part 1 - Background Information, Methodology and Maps. Forum of European Geological Surveys (FOREGS), G.S. of Finland, Espoo (Also available at www.gsf.fi/publ/foregsatlas/index.php), 2005.

30 C. Reimann and P. De Caritat, Sci. Total Environ., 2005, 337, 91-107.

31 D. C. Adriano, Trace elements in terrestrial environments: biogeochemistry, bioavailability, and risks of metals, $2^{\text {nd }}$ ed. Springer-Verlag, New York, 2001, 867 pp.

32 A. Tremel, P. Masson, T. Sterckeman, D. Baize and M. Mench M., Environ. Poll., 1997, 95 (3), 293-302.

33 L. Laforte, A. Tessier, C. Gobeil and R. Carignan. Geochim. Cosmochim. Acta, 2005, 69 (22), 5295-5306.

34 Y. Gélinas, M. Lucotte and J.-P. Schmit, Atmos. Environ., 2000, 34, 1797-1810. 
Silver and thallium historical trends in an urban catchment

514

515

516

517

518

519

520

521

522

523

524

525

526

527

528

529

530

531

532

533

534

535

536

537

538

539

540

541

542

543

544

545

546
Table 1 Analytical information. Instrumental detection limits (including digestion blanks for ICP-MS; mg kg ${ }^{-1}$ ). Analysis of certified material GXR-1 (USGS). INAA: Instrumental Neutron Activation Analysis. ICP-MS: Inductively Coupled Plasma - Mass Spectrometry.

\begin{tabular}{llllll}
\multicolumn{2}{l}{ Quantification limits } & \multicolumn{2}{l}{ Reference material } \\
\hline & INAA & ICP-MS & Certified value & $\begin{array}{l}\text { Measured value } \\
\text { INAA }(\mathrm{n}=3)\end{array}$ & $\begin{array}{l}\text { Measured value } \\
\text { ICP-MS }(\mathrm{n}=3) \\
\mathrm{mg} \mathrm{kg}^{-1}\end{array}$ \\
& $\mathrm{mg} \mathrm{kg}^{-1}$ & $\mathrm{mg} \mathrm{kg}^{-1}$ & $\mathrm{mg} \mathrm{kg}^{-1}$ & $\mathrm{mg} \mathrm{kg}^{-1}$ & n.d. \\
$\mathrm{Sc}$ & 0.1 & n.d. & $1.58 \pm 0.20$ & $1.7 \pm 0.1$ & $31 \pm 3$ \\
$\mathrm{Ag}$ & 1 & 0.005 & $31 \pm 4$ & $33 \pm 3$ & $0.40 \pm 0.02$ \\
$\mathrm{TI}$ & n.d. & 0.001 & $0.39 \pm 0.20^{\mathrm{a}}$ & n.d. &
\end{tabular}

(a) Provisional concentration value; n.d. not determined

Table 2 Scandium (Sc), silver (Ag) and thallium (Tl) geochemical background values in the upper continental crust (literature) and in suspended sediment collected at upstream stations of the Seine River basin $\left(\mathrm{mg} \mathrm{kg}^{-1}\right)$.

\begin{tabular}{|c|c|c|c|c|c|c|c|c|c|c|}
\hline \multirow{2}{*}{\multicolumn{2}{|c|}{ Unner continental crust }} & \multicolumn{3}{|l|}{ Sc } & \multicolumn{3}{|l|}{$\mathrm{Ag}$} & \multicolumn{3}{|l|}{$\mathrm{TI}$} \\
\hline & \multicolumn{10}{|c|}{ Upper continental crust } \\
\hline \multicolumn{2}{|c|}{ Taylor and McLennan (1985) } & \multicolumn{3}{|l|}{11} & \multicolumn{3}{|l|}{0.050} & \multicolumn{3}{|l|}{0.75} \\
\hline \multicolumn{2}{|c|}{ Wedepohl (1995) } & 7 & & & 0.055 & & & 0.75 & & \\
\hline \multicolumn{11}{|c|}{ Local background stations } \\
\hline \multirow[t]{3}{*}{ Marnay-sur-Seine } & Dec 08 & $6.6^{\mathrm{a}}$ & \pm & 0.1 & $0.24^{b}$ & \pm & 0.01 & $0.32^{b}$ & \pm & 0.02 \\
\hline & Jan 09 & $6.6^{\mathrm{a}}$ & \pm & 0.1 & $0.25^{b}$ & \pm & 0.01 & $0.31^{b}$ & \pm & 0.02 \\
\hline & Feb 09 & $6.7^{\mathrm{a}}$ & \pm & 0.1 & $0.50^{b}$ & \pm & 0.02 & $0.27^{b}$ & \pm & 0.01 \\
\hline \multirow[t]{2}{*}{ Méry-sur-Marne } & Apr 06 & $7.0^{\mathrm{a}}$ & \pm & 0.1 & $0.59^{b}$ & \pm & 0.03 & $0.43^{b}$ & \pm & 0.02 \\
\hline & Jan 07 & $7.6^{\mathrm{a}}$ & \pm & 0.1 & $0.59^{b}$ & \pm & 0.03 & $0.48^{b}$ & \pm & 0.02 \\
\hline
\end{tabular}

(a) INAA determinations

(b) ICP-MS determinations 
Silver and thallium historical trends in an urban catchment

Table 3 Scandium $(\mathrm{Sc})$, silver $(\mathrm{Ag})$ and thallium $(\mathrm{Tl})$ concentrations values in the $\mathrm{B} 2$ core $\left(\mathrm{mg} \mathrm{kg}^{-1}\right)$. (n.d. not determined)

\begin{tabular}{|c|c|c|c|c|c|c|c|c|c|}
\hline Year & Sc & & & $\mathrm{Ag}$ & & & $\mathrm{Tl}$ & & \\
\hline 2003 & 9.5 & \pm & 0.8 & 3.8 & \pm & 0.4 & n.d. & & \\
\hline 1997 & 7.2 & \pm & 0.6 & 7.9 & \pm & 0.8 & 0.70 & \pm & 0.04 \\
\hline 1994 & 8.0 & \pm & 0.6 & 13.1 & \pm & 1.3 & 0.95 & \pm & 0.05 \\
\hline 1989 & 9.3 & \pm & 0.7 & 10.7 & \pm & 1.1 & 0.92 & \pm & 0.05 \\
\hline 1986 & 10.3 & \pm & 0.8 & 7.4 & \pm & 0.7 & n.d. & & \\
\hline 1985 & 9.8 & \pm & 0.8 & 9.2 & \pm & 0.9 & 0.84 & \pm & 0.04 \\
\hline 1983 & 9.6 & \pm & 0.8 & 10.5 & \pm & 1.0 & 0.87 & \pm & 0.04 \\
\hline 1979 & 9.5 & \pm & 0.8 & 11.3 & \pm & 1.1 & 0.66 & \pm & 0.03 \\
\hline 1974 & 9.1 & \pm & 0.7 & 15.5 & \pm & 1.5 & 0.77 & \pm & 0.04 \\
\hline 1967 & 9.6 & \pm & 0.8 & 22.4 & \pm & 2.2 & 0.97 & \pm & 0.05 \\
\hline 1963 & 10.5 & \pm & 0.8 & 24.6 & \pm & 2.5 & 0.80 & \pm & 0.04 \\
\hline 1960 & 9.7 & \pm & 0.8 & 20.8 & \pm & 2.1 & 1.01 & \pm & 0.05 \\
\hline 1956 & 10.1 & \pm & 0.8 & 20.4 & \pm & 2.0 & n.d. & & \\
\hline 1949 & 9.0 & \pm & 0.7 & 8.8 & \pm & 0.9 & n.d. & & \\
\hline 1943 & 9.2 & \pm & 0.7 & 9.9 & \pm & 1.0 & 0.99 & \pm & 0.05 \\
\hline
\end{tabular}

Table 4 Scandium (Sc) and silver (Ag) concentrations values in the M1 core $\left(\mathrm{mg} \mathrm{kg}^{-1}\right)$ (n.d. not determined).

\begin{tabular}{llllllllll}
\hline Year & Sc & & & $\mathrm{Ag}$ & & & $\mathrm{Tl}$ & & \\
\hline 2002 & 7.7 & \pm & 0.6 & 4.4 & \pm & 0.4 & 0.54 & \pm & 0.03 \\
1995 & 6.0 & \pm & 0.5 & 4.6 & \pm & 0.5 & 0.50 & \pm & 0.03 \\
1988 & 6.9 & \pm & 0.6 & 6.1 & \pm & 0.6 & 0.56 & \pm & 0.03 \\
1986 & 6.7 & \pm & 0.5 & 6.1 & \pm & 0.6 & n.d. & & \\
1983 & 5.7 & \pm & 0.5 & 6.8 & \pm & 0.7 & 0.49 & \pm & 0.02 \\
1980 & 5.7 & \pm & 0.5 & 6.7 & \pm & 0.7 & n.d. & & \\
1970 & 6.9 & \pm & 0.6 & 14.3 & \pm & 1.4 & 0.64 & \pm & 0.03 \\
1968 & 6.4 & \pm & 0.5 & 11.9 & \pm & 1.2 & 0.49 & \pm & 0.02 \\
1961 & 8.0 & \pm & 0.6 & 13.6 & \pm & 1.4 & 0.64 & \pm & 0.03 \\
1957 & 8.9 & \pm & 0.7 & 8.7 & \pm & 0.9 & 0.68 & \pm & 0.03 \\
1951 & 7.4 & \pm & 0.6 & 4.7 & \pm & 0.5 & n.d. & & \\
1943 & 9.0 & \pm & 0.7 & 9.6 & \pm & 1.0 & 1.36 & \pm & 0.07 \\
1936 & 8.6 & \pm & 0.7 & 9.1 & \pm & 0.9 & n.d. & & \\
1933 & 7.5 & \pm & 0.6 & 6.2 & \pm & 0.6 & 0.67 & \pm & 0.03 \\
\hline
\end{tabular}


Silver and thallium historical trends in an urban catchment

562 Table 5 Silver (Ag) and thallium (Tl) enrichment factors in the B2 and M1 cores, and in the 563 upstream sites. Ref: upper continental crust reference concentrations used for the calculation 564 of enrichment factors (Wedepohl, 1995). See text for details.

565

\begin{tabular}{|c|c|c|c|c|c|}
\hline \multirow{2}{*}{$\begin{array}{l}\text { B2 core } \\
\text { Year }\end{array}$} & \multicolumn{5}{|c|}{ M1 core } \\
\hline & $\mathrm{Ag}$ & $\mathrm{Tl}$ & Year & $\mathrm{Ag}$ & $\mathrm{Tl}$ \\
\hline 2003 & 51 & & 2002 & 73 & 0.65 \\
\hline 1997 & 140 & 0.91 & 1995 & 98 & 0.78 \\
\hline 1994 & 208 & 1.11 & 1988 & 112 & 0.76 \\
\hline 1989 & 146 & 0.93 & 1986 & 116 & \\
\hline 1986 & 92 & & 1983 & 152 & 0.79 \\
\hline 1985 & 119 & 0.79 & 1980 & 151 & \\
\hline 1983 & 139 & 0.84 & 1970 & 263 & 0.86 \\
\hline 1979 & 153 & 0.65 & 1968 & 235 & 0.71 \\
\hline 1974 & 217 & 0.79 & 1961 & 217 & 0.75 \\
\hline 1967 & 296 & 0.94 & 1957 & 124 & 0.72 \\
\hline 1963 & 300 & 0.72 & 1951 & 81 & \\
\hline 1960 & 272 & 0.97 & 1943 & 136 & 1.41 \\
\hline 1956 & 256 & & 1936 & 135 & \\
\hline 1949 & 124 & & 1933 & 105 & 0.84 \\
\hline 1943 & 137 & 1.01 & & & \\
\hline Marnay (Dec 08) & 4.6 & 0.45 & & & \\
\hline Marnay (Jan 09) & 4.9 & 0.45 & & & \\
\hline Marnay (Feb 09) & 9.5 & 0.37 & & & \\
\hline Méry (Apr 06) & 10.7 & 0.57 & & & \\
\hline Méry (Jan 07) & 9.9 & 0.59 & & & \\
\hline $\operatorname{Ref}\left(m g k g^{-1}\right)$ & 0.055 & 0.75 & & 0.055 & 0.75 \\
\hline
\end{tabular}


Silver and thallium historical trends in an urban catchment

Figure 1 (a) Location of the B2 and M1 sediment cores and the suspended sediment sampling sites (Marnay-sur-Seine and Méry-sur-Marne) in the Seine River basin. (b) Location of the currently operational $\mathrm{Pb}$ industries in the upstream part of the Seine catchment and in the Marne catchment (Source: IREP, 2009).

(a)

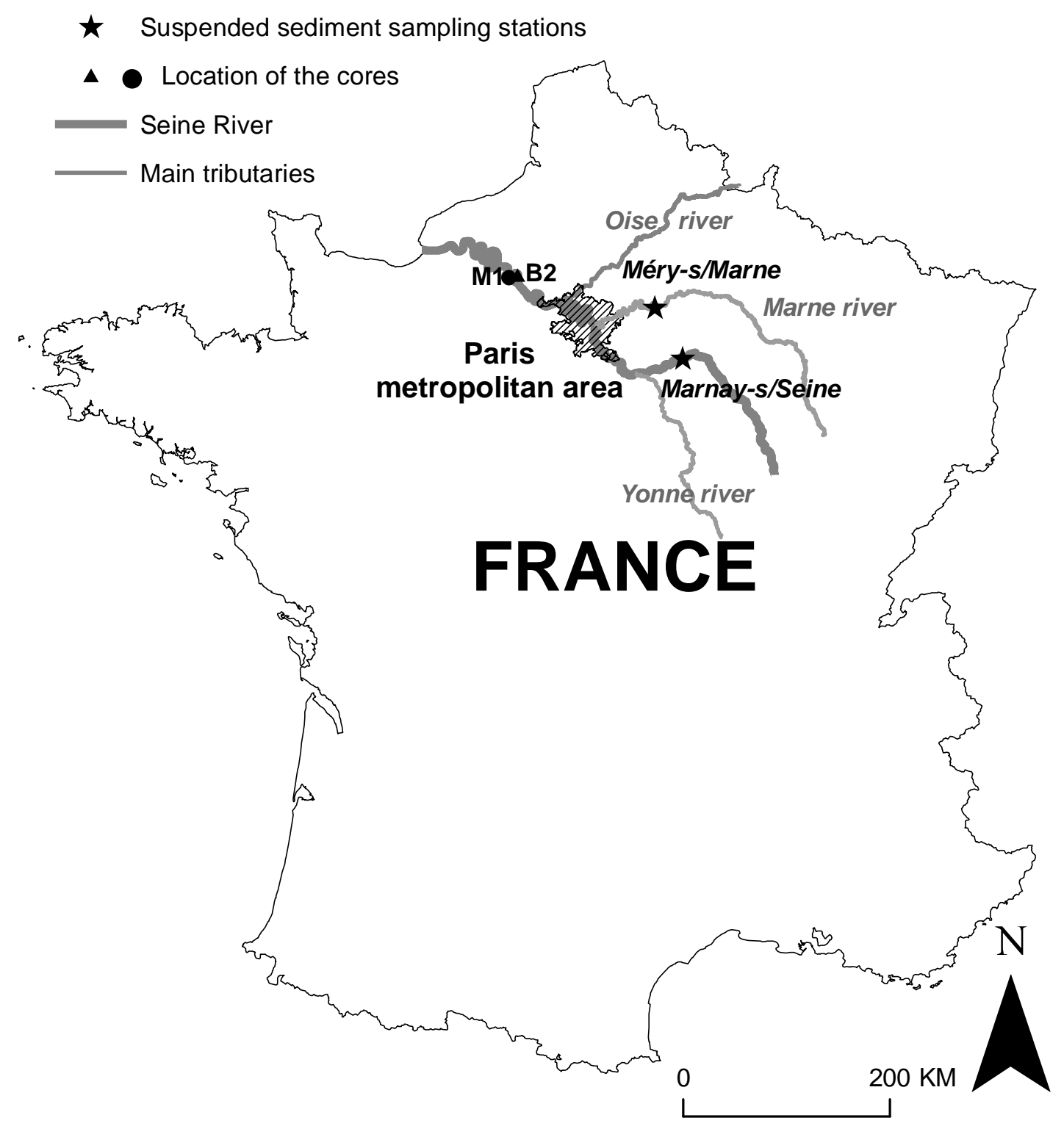


Silver and thallium historical trends in an urban catchment

588

589

590 (b)

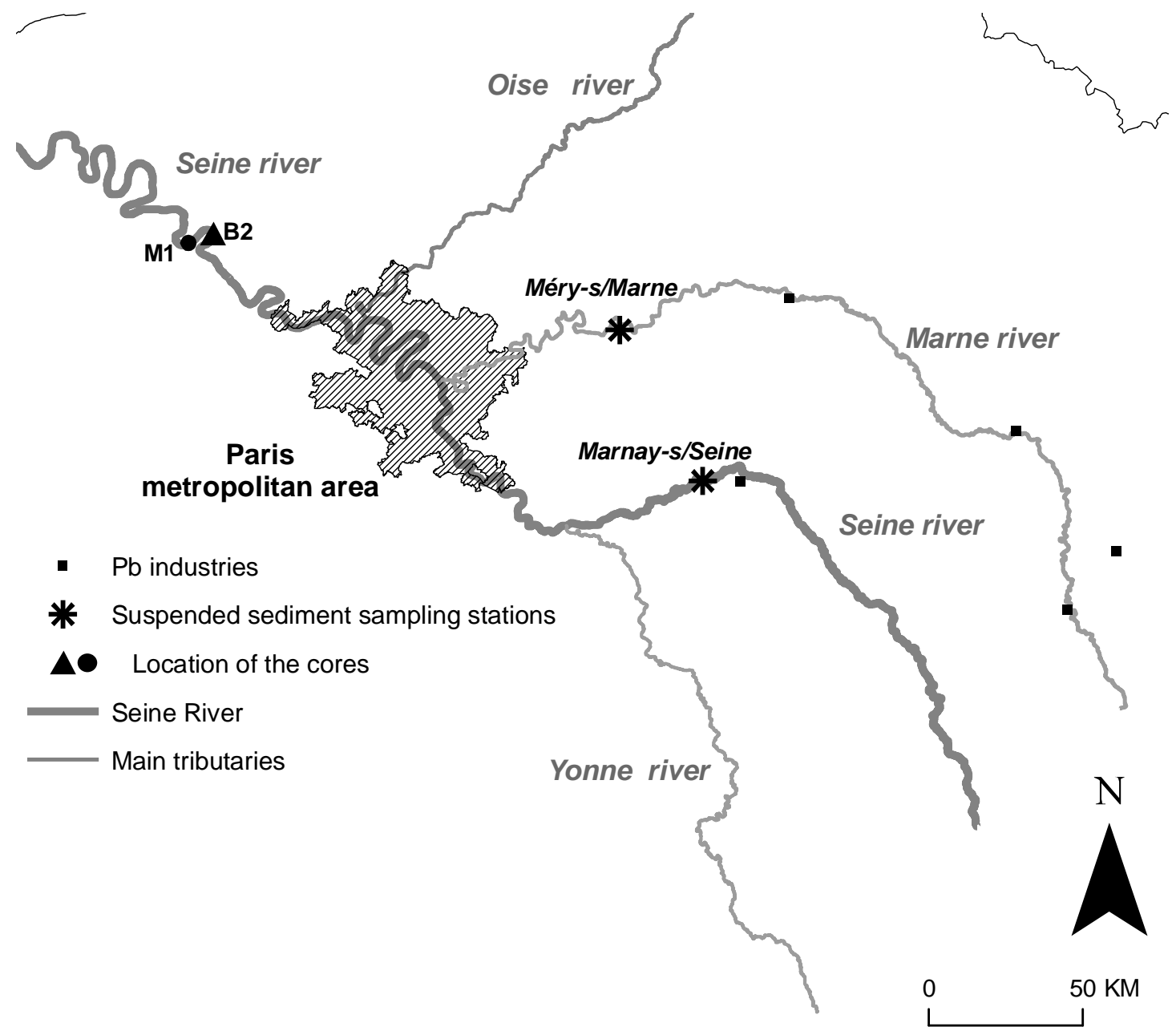


Figure 2 Depth profiles of the Cs-137 activity. (a) ( $\mathbf{\Delta}$ ) B2 core (Bouafles); (b) (•) M1 core (Muids). (a) The chronology derived from the measured activities is indicated on the right axis of the graph for the B2 core. (c) Due to changes in the deposition rate along the depth profile of the M1 core, its chronological profile is shown in a separated graph.

\section{$137 \mathrm{Cs}(\mathrm{Bq} / \mathrm{kg})$}

(a)

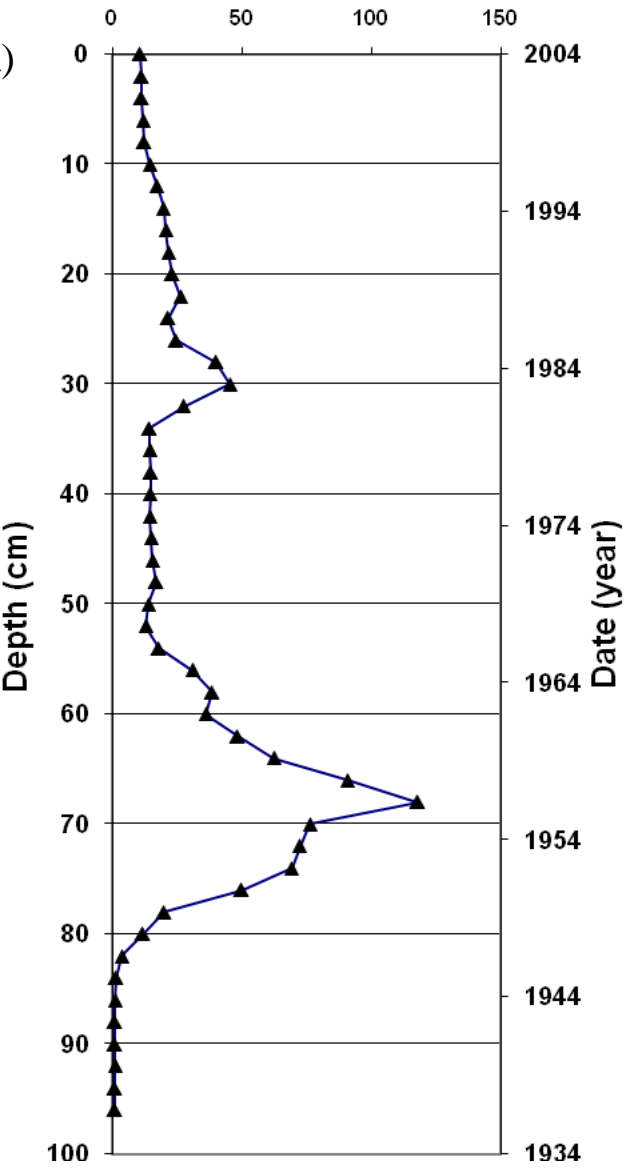

137 Cs (Bqlkg)

(b)

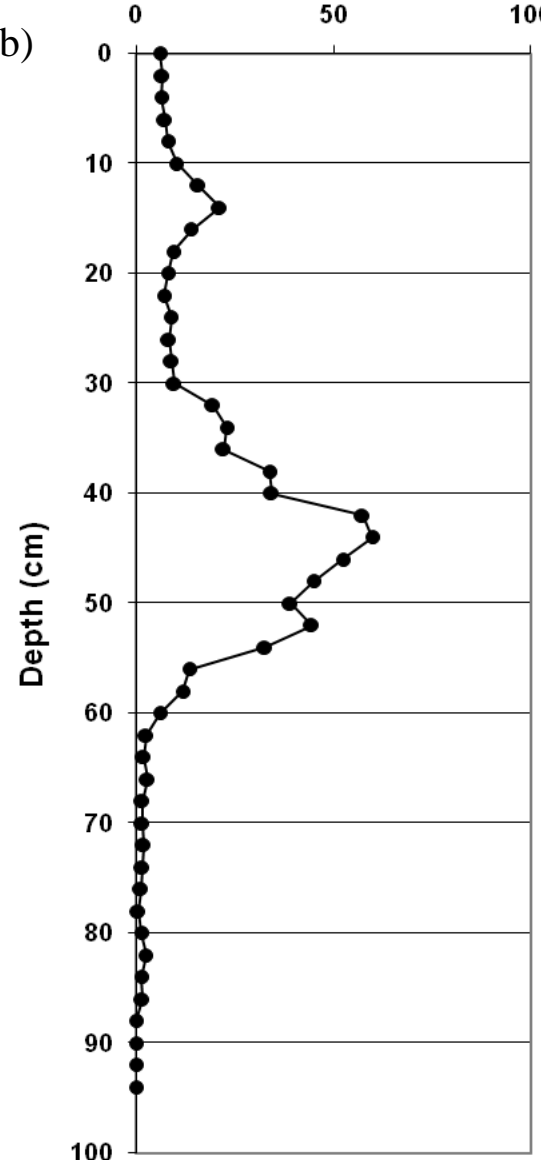

$137 \mathrm{Cs}(\mathrm{Bq} / \mathrm{kg})$

(c)

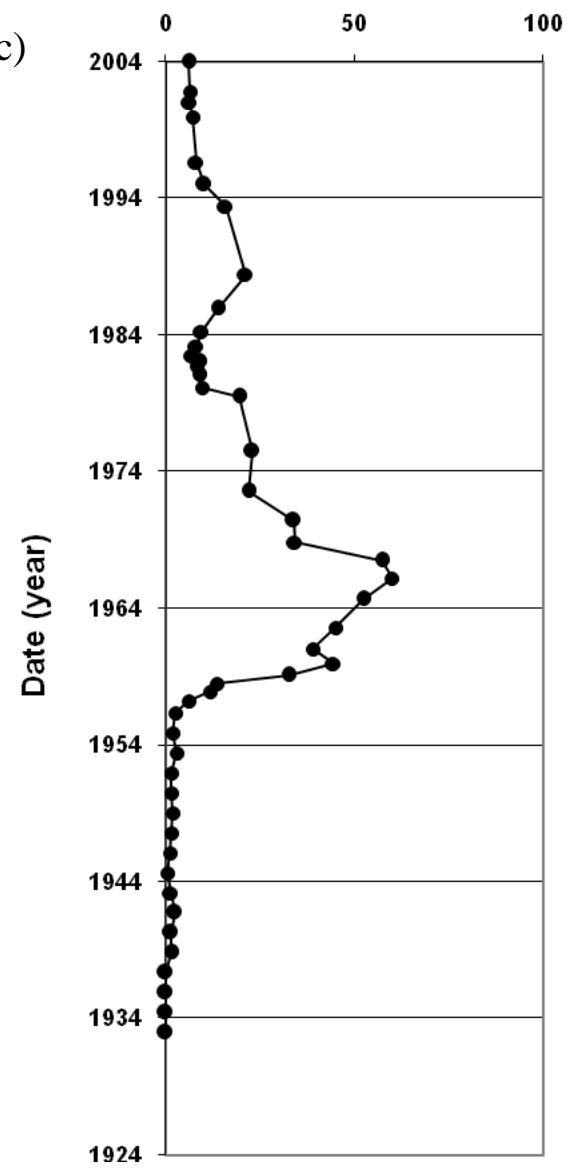


Silver and thallium historical trends in an urban catchment

602

603

604

605

606
607

608

609

610

611

612

613

614

615

616

617

618

619

620

621

622

623

624

625
Figure 3 Enrichment factor $(\mathrm{EF})$ in $\mathrm{Ag}$ in the depth profiles of the two analysed cores: $(\mathbf{\Delta})$ B2 core (Bouafles); $(\bullet)$ M1 core (Muids) using upper continental crust values as reference.

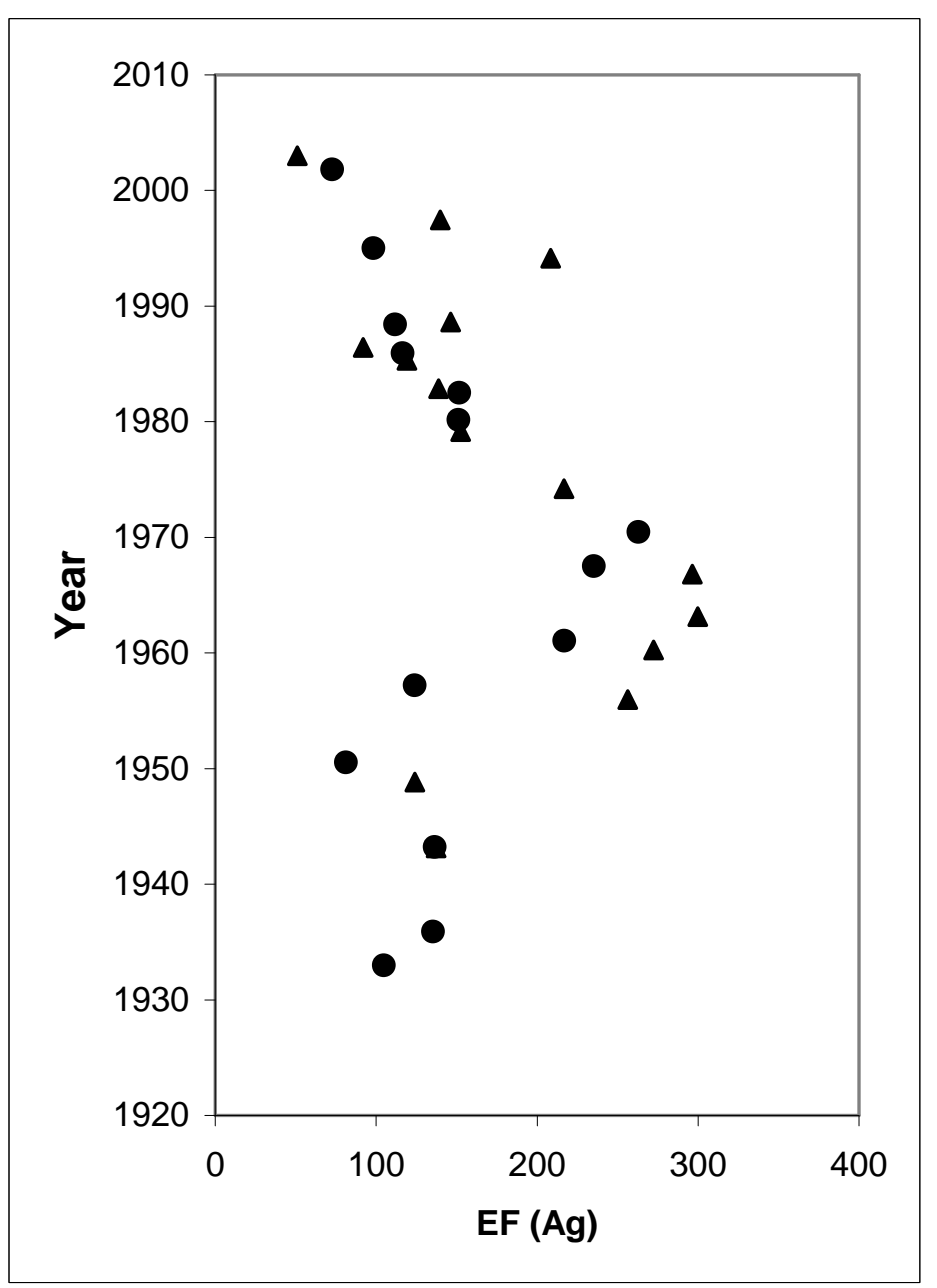

\section{Impact statement}

This manuscript reports the temporal evolution of silver (Ag) and thallium (Tl) concentrations in sediment cores. These cores, issued from downstream Seine River flood plains, represent extraordinary archives of the sediments flowing across Paris conurbation. Ag and $\mathrm{Tl}$ are two toxic metals, released to the environment by human activities and scarcely documented in river sediment. The present work shows a huge Ag sediment contamination around 1960. In contrast, no contamination was registered for Tl. These findings increase the understanding of $\mathrm{Ag}$ and $\mathrm{Tl}$ environmental cycles in urban environments. In addition, the $\mathrm{Ag}$ and $\mathrm{Tl}$ geochemical background concentrations in the Seine River were documented. Ag concentrations were tenfold higher than the Ag background values reported for the upper continental crust. This emphasizes the need to increase the research efforts on silver and 
Silver and thallium historical trends in an urban catchment

626 thallium that have been understudied in an environmental context, whereas the uses of Ag are 627 dramatically increasing.

628 


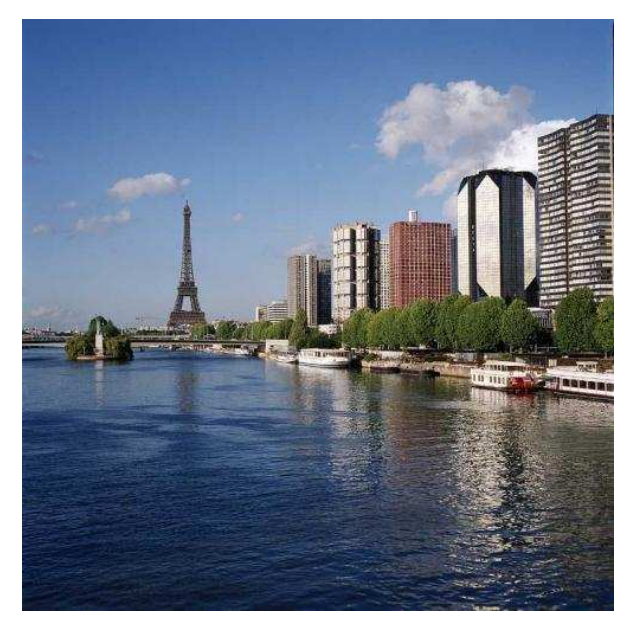

Environmental archives showed that the Seine River (France) was severely contaminated by silver during the last century. 